\title{
Generic drug competition: The pharmaceutical industry "gaming" controversy
}

\section{Thomas A. Hemphill}

School of Management, University of Michigan - Flint, Flint, Michigan, USA

\section{Correspondence}

Thomas A. Hemphill, David M. French Distinguished Professor of Strategy, Innovation and Public Policy, School of Management, University of Michigan Flint, Flint, MI 48502.

Email: thomashe@umich.edu

\begin{abstract}
Among American adults 20 years and older, 59 percent take at least one prescription drug on a regular basis. Unlike most branded drugs, which are generally drugs that have a trade name and are protected by a patent, off-patent generic drugs make up approximately 90 percent of prescriptions annually filled in the United States; yet in 2017, generic drugs made up only 23 percent of total drug costs in the U.S. The U.S. Food and Drug Administration has taken the lead in encouraging increased competition in the nation's prescription drug marketplace, most recently with its release of the agency's Drug Competition Action Plan, but also with its regulatory guidance and enforcement efforts to eliminate "gaming" of the regulatory process by both branded and generic pharmaceutical manufacturers. Such "gaming" activities include "pay-for-delay" agreements involving financial compensation between branded and generic pharmaceutical manufacturers to forestall the emergence into the market of generic pharmaceuticals to compete against a formerly patent-protected branded drug. A combination of new enabling legislation, federal judicial guidance, and agency regulatory activities show promise in encouraging increased competition in the prescription drug marketplace, with the American consumer the ultimate beneficiary of lower health care costs and improved overall personal health.
\end{abstract}




\section{K E Y W O R D S}

branded drugs, Federal Trade Commission, Food and Drug

Administration, generic drugs, patents, pay-for-delays

A recent study published in the Journal of the American Medical Association (Kantor, Rehm, Haas, Han, \& Giovannucci, 2015) found that, among American adults 20 years and older, 59 percent take at least one prescription drug on a regular basis. Unlike most branded drugs, which are generally drugs that have a trade name and are protected by a patent, off-patent generic drugs (that have the same bioequivalent active ingredients as the original patent protected, branded pharmaceutical) make up approximately 90 percent of prescriptions annually filled in the United States in 2017 (Association for Accessible Medicines, 2018). Furthermore, in 2017, generic drugs made up only 23 percent of total drug costs in the United States (Association for Accessible Medicines, 2018), thus providing generally low-cost relief for the overwhelming majority of Americans who are presently afflicted with a variety of long-term, health-related maladies.

According to data retrieved from the Express Scripts Prescription Price Index (2017), between January 1, 2008 and January 2016, the price of branded drugs rose 208 percent to an average price per prescription of $\$ 307.86$; in contrast, the price of generic drugs to U.S. consumers fell $\$ 26.27$ to $\$ 114.38$ per prescription. Moreover, according to the Association for Accessible Medicines (2018), generic drugs saved the U.S. healthcare system \$1.65 trillion over the last decade (through 2017), with a 2017 annual savings of \$265.1 billion. The U.S. Department of Health and Human Services (2016) reports "that decreases in generic drug prices have partially offset large increases in prices for brand drugs" and "that generic drug prices are not an important part of the drug cost problem facing the nation."

Yet, since 2010, the U.S. Government Accountability Office (GAO) (2016) found that prices of 315 generic drugs had seen extraordinary price increases of "at least 100 percent." The GAO (2016) report also notes that "drugs with extraordinary price increases moderated the overall decline in generic drug prices" as generic drug prices declined 59 percent from the first quarter of 2010 through the second quarter of 2015. Thus, the impact of these extraordinary price increases is mitigated by the fact that the vast majority of the drugs that experienced these extraordinary price increases were not listed among the 100 most commonly used generic drugs listed under Medicare Part D (the focus of this GAO study).

\section{GENERIC DRUG FEES AND REGULATORY REVIEW COSTS}

Since 2012, the U.S. Food and Drug Administration's (FDA) Office of Generic Drugs (OGD) has benefited from the passage of the Generic Drug User Fee Amendments (GDUFA). The GDUFA helps expedite the regulatory review process for generic pharmaceutical manufacturers, and the recently enacted FDA Reauthorization Act of 2017 includes the re-authorization of the Generic Drug User Fee Amendments for another 5 years (Berndt, Conti, \& Murphy, 2018). In addition, industry-paid generic drug user fees will total \$493 million in fiscal year 2018, up from \$299 million in fiscal year 2013, the first year FDA collected user fees (Gafney, 2018). Generic user fees account for 7 percent of the FDA's annual budget and allow the FDA to hire more review staff and make infrastructure improvements (Gafney, 2018). The GDUFA keeps individual generic drug manufacturers assessments fees as low as possible to supplement appropriated funding and provide the FDA with the ability to perform 
critical program review functions involving manufacturer facilities safety, consumer drug access, and transparency in the global pharmaceutical supply chain that would not otherwise occur (Berndt et al., 2018). However, a common criticism of this Act is that such exorbitant fees charged by the FDA to regulate generic drug manufacturers has led to the dramatic increases in generic drug prices cited, for example, in the GAO report (U.S. Government Accountability Office, 2016).

As part of its review, the GAO interviewed five generic pharmaceutical manufacturers, including major manufacturers Mylan, Sandoz, and Teva, as well smaller manufacturers G\&W Laboratories, and Nephron Pharmaceuticals, to solicit their views on generic drug pricing (U.S. Government Accountability Office, 2016). The general response from these manufacturers was that competition is the major factor in generic drug pricing, meaning that company drug pricing is dependent on the price and availability of the bioequivalent drug of their competitors (U.S. Government Accountability Office, 2016). Generally, competition between branded and generic pharmaceutical manufacturers provides consumers tremendous savings. For example, when a generic pharmaceutical competitor enters the market against a branded pharmaceutical competitor, drug prices drop to 70 to 80 percent of the brand-name counterpart, and the generic competitor gains substantial share from the brand-name product in a short period (Congressional Budget Office, 1998). Subsequent generic entrants may enter at even lower prices—discounted 80 percent or more off the price of the brand-name drug-which, in turn, prompts the earlier generic entrants to reduce their prices further (Congressional Budget Office, 1998).

The GAO also found that generic drug prices could be negatively affected by supply disruptions to active pharmaceutical ingredients, production difficulties, consolidation among suppliers and buyers, and a backlog of new generic drug applications awaiting FDA review (Government Accountability Office, 2016). Nowhere, however, does the GAO mention the "exorbitant fees" assessed by the FDA for regulatory review to be a factor in the dramatic price increases listed by the surveyed generic drug manufacturers. Previously, the FDA had calculated that based on a reported 3.99 billion retail prescriptions dispensed in the United States in 2010, and with 78 percent of these prescriptions filled by generic drugs, the estimated regulatory cost of the GDUFA would be less than 10 cents per prescription (Government Accountability Office, 2016). Yet, the FDA also noted that with the adoption of GDUFA user fees, and the associated savings in manufacturer drug development time, the total cost of bringing a generic drug to market may decline and result in reduced costs (Government Accountability Office, 2016).

\section{I IMPROVED FDA REGULATORY PROCESSING TIMES}

The OGD is responsible for ensuring, through a scientific and regulatory process, that Americans receive safe, effective, and high-quality generic drugs (U.S. Food and Drug Administration, 2018a). For calendar year 2017, the OGD approved the combined highest number (841) of abbreviated new drug applications (ANDAs) drug approvals and tentative approvals (184) - 1,027 total generic drug approvals - in the history of the generic drug program (U.S. Food and Drug Administration, 2018c). In addition, the OGD issued first approvals for generic versions of such commonly used drugs including Strattera, Truvada, Coreg CR, Effient, Renvela, and Vytorin. Furthermore, the OGD published 178 product-specific guidance documents and 17 general guidance documents for use by industry to develop generic drugs (U.S. Food and Drug Administration, 2018c). Moreover, for ANDAs approved, the median approval process time has declined from about 24 months in FY2013 to under 15 months for FY2015 - a staggering reduction from the 42- to 44-month median approval time prior to passage of the GDUFA in 2012 (Sullivan, 2018a). 
This approval time is still not at the level of new drug approvals (NDAs), which are more complex and presently take from 6 to10 months to review (U.S. Food and Drug Administration, 2018b). The good news is that under the next iteration of the GDUFA in 2018, the median standard review time for generic ANDAs will be 10 months from submission, while priority review will be 8 months from submission (Sullivan, 2018a). This projected improvement in agency performance will effectively eliminate the "backlog" of new generic drug applications awaiting FDA review. It is also strong evidence of the success of user fees in getting many essential generic drugs safely to the American consumer.

\section{3 | THE FDA DRUG COMPETITION ACTION PLAN}

However, the generic pharmaceutical industry needs to step up to embrace increased competition, too. As RBC Capital Markets noted in a 2016 study (Brennan, 2016), the generic pharmaceutical industry had only 23 "innovator" drugs, that is, generic drugs that can introduce competition against an established off-patent brand, pending at the OGD. Moreover, RBC Capital Markets data reveal that the lack of generic competition is not primarily an issue of the OGD's speed in facilitating the review of generic drugs to market, but in industry submitting applications that would create this competition (Brennan, 2016). The RBC found that there are 125 additional "innovator" drugs with no approved generics and no abbreviated new drug approvals submitted to the FDA (Brennan, 2016).

The new Trump administration-appointed FDA Commissioner, Scott Gottlieb wasted little time in announcing that his agency would change the generic drug approval process with a focus on further lowering consumer prices.

No patient should be priced out of the medicines they need, and as an agency dedicated to promoting public health, we must do our part to help patients get access to the treatments they require, said Gottlieb. Getting safe and effective generic products to market in an efficient way, being risk based in our work and making sure our rules aren't used to create obstacles to new competition can help make sure that patients have access to more lower-cost options (U.S. Food and Drug Administration, 2017b).

Under its Drug Competition Action Plan, the FDA (in May 2017) posted (and will continue to refine and update on the Internet) a list of branded drugs that have no listed patents or drug exclusivities (granted by the FDA) and for which the agency has yet to approve an ANDA application (U.S. Food and Drug Administration, 2017b). The FDA has updated this list in December 2017 (U.S. Food and Drug Administration, 2018d) and June 2018 (Syrop, 2018). The FDA also intends to expedite the review of any generic drug application for a product on this list to ensure that they come to market as soon as possiblewith its intended goal being eight months of submission for approval (reduced from the agency's existing 10-month benchmark) (U.S. Food and Drug Administration, 2018d). This FDA goal mirrors language appearing in the recently enacted FDA Reauthorization Act of 2017. In addition, the FDA also announced that it will change its policy on how it will prioritize its review of generic drug applications, expediting the review of generic drug applications until there are three approved generics for a given branded drug product (U.S. Food and Drug Administration, 2018d).

In a June 21, 2017 blog posting, FDA Commissioner Gottlieb noted (U.S. Food and Drug Administration, 2017a): 
We know that sometimes our regulatory rules might be "gamed" in ways that may delay generic drug approvals beyond the time frame the law intended, in order to reduce competition. We are actively looking at ways our rules are being used and, in some cases misused. ... I want to take steps to address these concerns, to make sure that we are facilitating appropriate competition where Congress intended.

Some examples of how such "gaming" goes on include, first, increasing the unavailability of certain branded products for comparative testing, as branded companies may be deliberately using commercial techniques to block a generic company from getting access to testing samples (U.S. Food and Drug Administration, 2017a). This regulatory strategy uses restrictions placed in commercial contracts or agreements with to make it difficult for intermediaries in the pharmaceutical supply chain to sell the drugs to generic drug developers. Second, in some cases, branded sponsors may use limited distribution arrangements, whether the company has voluntarily adopted limited distribution, or the limitations imposed as part of a Risk Evaluation and Mitigation Strategy (REMS) as a basis for blocking generic firms from accessing the testing samples that they need (U.S. Food and Drug Administration, 2017a). Third, some branded companies may be using the statutory default requirement to have a single shared REMS across both the branded and generic versions of a drug (U.S. Food and Drug Administration, 2017a). This is a way to block generic entry, prolonging negotiations with the generic firms over the implementation of these single shared systems, and resulting in the generic reaching the consumer marketplace (U.S. Food and Drug Administration, 2017a). Gottlieb promises that the FDA will "be looking hard at how best to coordinate with the Federal Trade Commission (FTC) in identifying and publicizing practices that the FTC finds to be anti-competitive," as the FTC is the primary agency responsible for preventing such anticompetitive business practices (U.S. Food and Drug Administration, 2017a).

In 2018, the FDA has been active in implementing their Drug Competition Action Plan. For example, in January 2018, the FDA released two documents that streamline and improve aspects of the submission and review of generic drug applications (ANDAs) (U.S. Food and Drug Administration, 2018c). Later, in May 2018, the FDA announced that it was taking significant steps to support complex generic drug development and application review; prioritizing the review of certain generic drugs; publishing a list of off-patent, off-exclusivity branded drugs; and enhancing the efficiency of certain aspects of the submission process for generic drug applications (U.S. Food and Drug Administration, 2018e).

Later, in July 2018, the FDA announced the release of the agency's Biosimilars Action Plan, an important component of the Administration's recently announced Blueprint to Lower Drug Plans (U.S. Food and Drug Administration, 2018f; 2018g). While less than 2 percent of Americans use biologics, they currently represent 40 percent of total spending on prescription drugs (U.S. Food and Drug Administration, 2018f). Also in July 2018, the FDA announced the formation of a working group focused on developing importation policy options to address access challenges related to certain sole-source (i.e., single approved U.S. manufacturer) medicines with limited patient availability, but having no blocking patents or drug exclusivities (U.S. Food and Drug Administration, 2018h). Under these circumstances, which often can involve generic medicines, patients can be confronted with a drug shortage, and leaving them without access to their needed prescription drugs.

Most recently, in October 2018, the FTC announced that it would be addressing "gaming" tactics employed by branded firms to extend a drug monopoly beyond its patent expiration (U.S. Food and Drug Administration, 2018i). Specifically, when branded companies make it difficult for generic pharmaceutical manufacturers to gain access to physical doses of a branded drug, as these manufacturers need between 2,000 and 5,000 doses of the branded drug to run FDA required studies to prove their generic medicine is the bioequivalent of the branded drug. The use of so-called "citizen petitions" improperly filed by companies under section 505(q) of the U.S. Food, Drug and Cosmetics Act 
has been criticized as an anticompetitive action to block generic drug approvals, although the record shows that they have rarely delayed specific generic drug entry to the market. The FDA will release revised draft guidance describing some of the factors the FDA will consider in determining whether a petition is submitted with the primary purpose of delaying the approval of a generic drug application. Furthermore, the guidance document also outlines the agency's intentions to refer such petitions deemed as "delaying" to the FTC for potential prosecution under the antitrust statutes.

\section{4 | PAY-FOR-DELAY SETTLEMENT AGREEMENTS}

Another public policy "gaming" concern involves the so-called "pay-for-delay" agreements (or reverse payment settlements) between brand-name pharmaceutical companies and generic pharmaceutical manufacturers to stifle competition from lower-cost generic medicines, usually by negotiating a specific entry date by the generic pharmaceutical manufacturer later (months, if not years) than it would have been absent any financial compensation (Bloomberg Law, 2017; McCaughan, 2017). Consumer advocates and the FTC say these brand-name drug makers have been able to sidestep competition by offering patent settlements to pay generic companies not to bring lower-cost alternatives to market.

Such pay-for-delay agreements have arisen in the context of the Drug Price Competition and Patent Term Restoration Act of 1984 ("Hatch-Waxman Act”) (Bloomberg Law, 2017; McCaughan, 2017). The Hatch-Waxman Act created an expedited FDA approval process for a generic drug manufacturer to seek market entry prior to the expiration of the brand drug manufacturer's patent. Under the HatchWaxman Act, to initiate this early entry, the generic pharmaceutical company may either (a) contest the validity of the patent or (b) argue that its new product does not infringe the brand-name drug's patent. If the generic pharmaceutical company is successful on proving its case on either of these grounds, the FDA will then approve the generic version for sale to American consumers.

Generic drug makers and brand manufacturers, the parties involved in the settlements, argue that "pay-to-delay" agreements have saved American consumers hundreds of billions of dollars. Typically, the generic can come to market before the expiration date of at minimum one patent at issue, and the certainty of the timing (specified in the agreement) benefits purchasers (McCaughan, 2017). Ralph G. Neas, president of the Generic Pharmaceutical Association (now the Association for Accessible Medicines), sums up the generic pharmaceutical industry's policy position on reverse settlements (Sullivan, 2018a):

\section{The current industry paradigm of challenging patents on branded drugs in order to bring new generics to market as soon as possible has produced $\$ 1.06$ trillion in savings over the past 10 years. The facts are clear. Patent settlements save. They are pro-competition, pro-consumer, and have saved consumers and taxpayers billions of dollars.}

However, these reverse payment settlements to forestall generic drug market entry have raised FTC concerns under the Sherman Antitrust Act, which prohibits inter-company agreements that unreasonably interfere with competition in the marketplace (Bloomberg Law, 2017). The FTC estimates that "pay-fordelay" agreements cost American consumers approximately $\$ 3.5$ billion annually in increased healthcare costs (Federal Trade Commission, 2010). However, these "pay-for-delay" agreements are not without controversy within the federal government, as back in 2011 the U.S. Department of Justice could not agree with the FTC on whether these arrangements should be challenged (Bloomberg Law, 2017). 
The federal judiciary, at both the district and Supreme Court level, has weighed in on the "pay-fordelay" issue. In a June 2013 decision, Federal Trade Commission v. Actavis, the U.S. Supreme Court ruled 5-3 that reverse payment settlements between branded and generic pharmaceutical companies should be subject to a legal "rule of reason" antitrust standard. The Supreme Court had agreed to hear the case after several federal circuit courts had rendered split decisions for and against plaintiffs since 2001 on which antitrust standard to apply. Consequently, challenges to these patent settlements will now require the federal judiciary to weigh the competitive effects of the settlements on a case-by-case basis, rather than the more industry-friendly "scope of the patent" test or "presumptively unlawful" standard (which is the standard advocated by the FTC). In its decision, the Supreme Court left it to the lower federal courts to decide how to apply a rule-of-reason standard. Under this Supreme Court precedent, that judicial process has already begun.

In June 2015, the Third Circuit Court ruled 3-0 (in King Drug Co. of Florence et al. v. SmithKlineBeecham Corp. et al.) that pharmaceutical patent settlements do not need to be in the form of a cash payout from a brand pharmaceutical manufacturer to a generic manufacturer. The Court held that such patent settlements could be in the form of other types of business considerations, for example, a promise not to manufacture its own generic brand, to be eligible for antitrust scrutiny as a pay-for-delay agreement.

"We believe that this no-AG [authorized generic] agreement falls under Actavia' rule because it may represent an unusual, unexplained reverse transfer of considerable value from the patentee to the alleged infringer and may therefore give rise to the inference that it is a payment to eliminate the risk of competition," wrote U.S. Circuit Judge Anthony J. Scirica for the panel. As the [Supreme] Court noted, these kinds of settlements are subject to the rule of reason.

The U.S. Supreme Court announced it would rule early in 2019 on whether a "pay-to-delay agreement between Abbott Laboratories' Solvay Pharmaceuticals Inc. and Watson Pharmaceuticals (along with two similar cases), a generic manufacturer, could be challenged under the Sherman Act (Sullivan, 2018b). The 11th Circuit Court of Appeals in Atlanta held that the pay-for-delay agreement over AndroGel did not constitute an illegal restraint of trade. This was the third time since 2003 that a federal circuit court has upheld such agreements (Sullivan, 2018b). The FTC alleges that Solvay entered into anticompetitive patent settlements (ranging from \$31 million to \$42 million annually) with Watson and generic drug manufacturers Par Pharmaceuticals Cos. and Paddock Holdings Inc. to delay the introduction of a generic competitor to Solvay's testosterone replacement drug AndroGel (Sullivan, 2018b). The Supreme Court's holding on this case (and similar cases) should provide needed clarification into which "pay-to-delay" agreements are worth pursuing by the agency.

\section{5 | FTC MONITORING AND ENFORCEMENT}

The FTC has monitored the generic pharmaceutical marketplace for over a decade (FY2004) and has been compiling and analyzing data on reverse payment settlements, with the highest number-40 potentially problematic "pay-for-delay" agreements-out of 140 reported settlements reported in FY2012 (Federal Trade Commission, 2016). The number (of potentially problematic agreements) dropped to 29 for FY2013, the year of the Supreme Court Federal Trade Commission v. Actavis decision, although the total number of settlements rose to 145 (Federal Trade Commission, 2016). For FY2014, the latest report issued by the agency (and year after the Federal Trade Commission 
v. Actavis decision, the FTC revealed that there were 21 potentially problematic reverse payment settlements out of 160, a nearly 50 percent reduction from FY2012 (Federal Trade Commission, 2016).

The FTC also reported that the so-called "AG agreements," in which brand drug manufacturers promised not to sell a competing authorized generic (AG) version of their branded drug, had fallen from 19 in FY2012, to four in FY2013 and five in FY2014 (Noonan, 2016). For FY2014, the FTC report noted that over 80 percent (either 81 or 87 percent, based on two data sample populations) of the patent disputes were resolved without any financial compensation from the brand manufacturer to the generic manufacturer and/or without restrictions on generic competition (Federal Trade Commission, 2016).

Meanwhile, historically, the FTC has vigorously pursued antitrust litigation for nearly two decades against branded pharmaceutical manufacturers who use pay-for-delay agreements with generic pharmaceutical companies, challenging these agreements as illegally stifling competition and maintaining economically (and legally) unjustified monopolies. This agency involvement goes back to 1997, when a federal court ruled in Mova v. Shala that the FTC's policy contradicted the reading of the HatchWaxman Act of 1984 regarding the 6-month exclusivity awarded to the first applicant to file an ANDA (McCaughan, 2017). Since 2000, the FTC has brought several antitrust cases challenging settlements that involved reverse payments (McCaughan, 2017).

The agency has had some successes, including its 2015 "pay-for-delay" $\$ 1.2$ billion settlement (an activity encouraged by the federal district courts) with pharmaceutical manufacturers Cephalon, and Teva, the FTC has continued to be actively involved in several "pay-for-delay" cases (Bloomberg Law, 2017; McCaughan, 2017). Yet, there are also failures. In May 2018, an administrative law judge dismissed an FTC "pay-to-delay" agreement complaint against generic pharmaceutical company Impax Laboratories, Inc. and brand manufacturer Endo Pharmaceuticals (Federal Trade Commission, 2018). The administrative law judge concluded that the FTC failed (under a rule-of-reason analysis) to prove that the agreement between the defendants violated section 5 if the Federal Trade Commission Act (Federal Trade Commission, 2018). The FTC counsel has filed an appeal for a review by the Commission members (Federal Trade Commission, 2018).

The FTC notes that potentially problematic "pay-for-delay" agreements between branded and generic companies may be declining, but they are still prevalent in the pharmaceutical marketplace (Federal Trade Commission, 2016). "When drug companies agree not to compete, consumers lose," said former FTC Chairman Jon Leibowitz (Sullivan, 2018b). In calendar year 2017, the agency reported that 28 "pay-for-delay" agreements reached in the pharmaceutical industry, with another 127 such business arrangements made between 2005 and 2011 (Sullivan, 2018b). Since the Supreme Court decision in Federal Trade Commission v. Actavis, however, attorneys working in the pharmaceutical industry observe that litigation is waning as pharmaceutical companies are turning away from considering reverse payment settlements and are contemplating the impact of circuit court rulings against these types of agreements (Kroh, 2017).

\section{6 | POLICY SOLUTIONS}

The recently announced FDA Drug Competition Action Plan is well underway, and is an important policy focus of the Trump administration, and a reasonable regulatory period for generic drug approvals is definitely in the offing. While the Drug Competition Action Plan is one of the FDA's highest priorities in 2018 and beyond, the responsibility for improving price competition rests with a pharmaceutical industry willing to commit its financial resources to manufacturing an array of bioequivalent 
pharmaceuticals against branded, off-patent products, and not actively engaging in reverse settlement agreements and other forms of "gaming" activities.

Since the 2013 Supreme Court decision, there has been a significant decrease in what the FTC terms "potentially problematic" pay-to-delay agreements initiated by branded pharmaceutical companies - although an insufficient time to seriously label it a consistent trend until further data are collected by the agency from FY 2015 onward. The FTC should focus its agency resources on continuing to assiduously monitor the pharmaceutical industry for such reverse settlement agreements that will not pass muster under the rule of reason antitrust standard, and intervene with litigation when necessary. Moreover, further guidance on how to apply this rule of reason standard will develop from future decisions made in the federal circuit courts and the U.S. Supreme Court.

In the 115th Congress, U.S. Senators Amy Klobuchar (D-MN) and Charles Grassley (R-IA) jointly introduced a bill (S.124), the "Preserve Access to Affordable Generics Act," which would essentially make illegal reverse payment agreements among drug companies. The bill is similar to legislation sponsored by Klobuchar and Grassley in the 114th Congress. "Outrageous pay-for-delay deals thwart competition and raise prescription drug prices for consumers," said Klobuchar. "This bill would prevent drug companies from engaging in these abusive dealings and ensures more timely access to affordable medicines," Grassley added. Bill S.124 is presently in the U.S. Senate's Committee on the Judiciary.

The purpose of the Act is twofold: (a) enhance competition in the pharmaceutical market by stopping anticompetitive agreements between brand-name and generic drug manufacturers that limit, delay, or otherwise prevent competition from generic drugs; and (b) support the purpose and intent of antitrust law by prohibiting anticompetitive practices in the pharmaceutical industry that harm consumers. It is noteworthy that the FTC has been a consistent supporter of passage of Congressional legislation ending all forms of pay-for-delay agreements.

The proposed legislation, however, contains one notable exception that may placate the pharmaceutical industry (Sullivan, 2018c): "If the parties to such agreement demonstrate by clear and convincing evidence that the procompetitive benefits of the agreement outweigh the anti-competitive effects of the agreement." This provision could keep the pay-for-delay practice alive, although its proponents would need to present compelling evidence of its benefits to the consumer (Sullivan, 2018c). This evidence includes the value to consumers, the form and amount of compensation, revenues under various scenarios, the time it takes for the generic to reach market under various scenarios, and any other information deemed to be relevant (Sullivan, 2018c). The burden of proof, however, falls upon the parties interested in entering into a reverse payments settlement.

Whether there is legitimate need for passage of S.124 (or its successor in the 116th Congress) may be partially answered by the FTC updating its review of "pay-for-delay" agreements in the pharmaceutical marketplace for more recent fiscal years. The direction of this data will give an indication of whether the rule of reason standard, in conjunction with further clarification by the federal judiciary, is positively influencing a further decline in what the FTC terms "potentially problematic reverse payment agreements" in the generic pharmaceutical marketplace.

\section{REFERENCES}

Association for Accessible Medicines. (2018, July 10). 2018 generic drug access \& savings: Access in jeopardy. Washington, DC: Author. Retrieved from https://accessiblemeds.org/sites/default/files/2018_aam_generic_drug_ access_and_savings_report.pdf

Berndt, E. R., Conti, R. M., \& Murphy, S. J. (2018, May). The generic drug user fee amendments: An economic perspective. Journal of Law and Biosciences, 5(1), 103-141. 
Bloomberg Law. (2017). Side effects: The evolving law of 'reverse payments' and its impact on drug litigation. Retrieved from https://www.bna.com/uploadedFiles/BNA_V2/Legal/Pages/Custom_Trials/BLAW/24378\%20BLW\%20REP $\% 20$ Points $\% 20$ of $\% 20$ Law $\% 20$ Side\%20Effects.pdf

Brennan, Z. (2016, November 1). Generic drug backlog at FDA: A dive into the confusing numbers. Regulatory Focus. Retrieved from https://www.raps.org/regulatory-focus\%e2\%84\%a2/news-articles/2016/11/generic-drug-backlog-atfda-a-dive-into-the-confusing-numbers

Congressional Budget Office. (1998, July). How increased competition from generic drugs has affected prices and returns in the pharmaceutical industry. Retrieved from http://www.cbo.gov/showdoc.cfm?index $=655 \&$ sequence $=0>$

Express Scripts. (2017, August 17). Generics deliver value still. Retrieved from http://lab.express-scripts.com/lab/insig hts/drug-options/generics-deliver-value-still

Federal Trade Commission. (2010, January). Pay-for-delay: How drug company pay-offs cost consumers billions, an FTC study. Washington, DC: Author.

Federal Trade Commission. (2016, January). Agreements filed with the Federal Trade Commission under the Medicare prescription drug improvement and Modernization Act of 2001: Overview of agreements filed in FT2014, A report of the Bureau of Competition. Retrieved from https://www.ftc.gov/system/files/documents/reports/agreementsfilled-federal-trade-commission-under-medicare-prescription-drug-improvement/160113mmafy 14rpt.pdf

Federal Trade Commission. (2018, May 24). Administrative law judge dismisses FTC antitrust complaint against generic pharmaceutical company Impax Laboratories. Retrieved from https://www.ftc.gov/news-events/press-relea ses/2018/05/administrative-law-judge-dismisses-ftc-antitrust-complaint

Gafney, A. (2018, August 21). Generic drug approvals are soaring at the FDA. PwC/United States. Retrieved from https://www.pwc.com/us/en/health-industries/healthcare-library/generic-drug-approvals-increasing.html

Kantor, E. D., Rehm, C. D., Haas, J. S., Chan, A. T., \& Giovannucci, E. L. (2015, November 3). Trends in prescription drug use among adults in the United States from 1998-2012. Journal of the American Medical Association, 314(17), 1818-1831.

Kroh, E. (2017, June 20). Actavis at 4: Pay-for-delay lawsuits receding. Law360. Retrieved from https://www.law360. com/articles/935490/actavis-at-4-pay-for-delay-lawsuits-receding

McCaughan, M. (2017, July 21). Patent Settlements. Prescription Drug Pricing, Health Policy Brief Series, No. 4, Health Affairs. Retrieved from https://www.healthaffairs.org/do/10.1377/hpb20170721.583967/full/healthpolicybri ef_170.pdf

Noonan, K. E. (2016, February 29). FTC issues report on ANDA settlement agreements. Patent Docs. Retrieved from http://www.patentdocs.org/hatch-waxman/

Sullivan, T. (2018a, May 4). FDA under pressure to speed up generic approvals. Policy \& Medicine. Retrieved from https://www.policymed.com/2017/04/fda-under-pressure-to-speed-up-generic-approvals.html

Sullivan, T. (2018b, May 6). The Supreme Court and 'pay for delay': The potential impact on pharma. Policy \& Medicine. Retrieved from https://www.policymed.com/2013/01/in-early-december-of-last-year-the-us-supremecourt-agreed-to-hear-a-case-to-decide-whether-agreements-between-brand-name.html

Sullivan, T. (2018c, May 6). Preserve access to affordable generics act: Congress proposes end to pay for delay. Policy \& Medicine. Retrieved from https://www.policymed.com/2013/03/preserve-access-to-affordable-generics-act-congr ess-proposes-end-to-pay-for-delay.html

Syrop, J. (2018, July 2). FDA updates list of drugs without approved generic competitor. Center for Biosimilars, U.S. Food and Drug Administration. Retrieved from https://www.centerforbiosimilars.com/news/fda-updates-list-ofdrugs-without-approved-generic-competition-

U.S. Department of Health and Human Services. (2016, January 27). Understanding recent trends in generic drug prices. Retrieved from https://aspe.hhs.gov/pdf-report/understanding-recent-trends-generic-drug-prices

U.S. Food and Drug Administration. (2017a, June 21). FDA working to lift barriers to generic drug competition. Retrieved from https://www.fda.gov/NewsEvents/Newsroom/FDAVoices/ucm612018.htm

U.S. Food and Drug Administration. (2017b, June 27). FDA tackles drug competition to improve patient access. Retrieved from https://www.fda.gov/newsevents/newsroom/pressannouncements/ucm564725.htm

U.S. Food and Drug Administration. (2018a). Who we are. Center for Drug Evaluation and Research, Office of Generic Drugs. Retrieved from https://www.fda.gov/aboutfda/centersoffices/officeofmedicalproductsandtobacco/cder/ ucm119100htm

U.S. Food and Drug Administration. (2018b). Step 4: FDA drug review. Retrieved from https://fda.gov/ForPatients/ Approvals/Drugs/ucm405570.htm 
U.S. Food and Drug Administration. (2018c, January 3). Statement from FDA commissioner Scott Gottlieb, M.D., on new steps to facilitate efficient generic drug review to enhance competition, promote access and lower drug prices. Retrieved from https://www.fda.gov/NewsEvents/Newsroom/PressAnnouncements/ucm622252.htm

U.S. Food and Drug Administration. (2018d, January). 2017 Annual Report, Office of Generic Drugs. Washington, DC: Author. Retrieved from https://www.fda.gov/media/111198/download

U.S. Food and Drug Administration. (2018e, May 11). Statement from FDA commissioner Scott Gottlieb, M.D., on the Trump administration's plan to Lower drug prices. Retrieved from https://www.fda.gov/NewsEvents/Newsroom/ PressAnnouncements/ucm607495.htm

U.S. Food and Drug Administration. (2018f, July). Biosimilars action plan: Balancing innovation and competition. Washington, DC: Author.

U.S. Food and Drug Administration. (2018g, July 18). Remarks from FDA commissioner Scott Gottlieb, M.D., as prepared for delivery at the Brookings Institution on the release of the FDA's Biosimilars Action Plan. Retrieved from https://www.fda.gov/NewsEvents/Newsroom/PressAnnouncements/ucm613881.htm

U.S. Food and Drug Administration. (2018h, July 19). Statement by FDA commissioner Scott Gottlieb, M.D., on the formation of a new work group to develop focused drug importation policy options to address access challenges related to certain sole-source medicines with limited patient availability, but no blocking patents or exclusivities. Retrieved from https://www.fda.gov/newsevents/newsroom/pressannouncements/ucm613931.htm

U.S. Food and Drug Administration. (2018i, October 2). Statement from FDA Commissioner Scott Gottleib, M.D., on new agency actions to further deter 'gaming' of the generic drug approval process by the use of citizen petitions. Retrieved from https://www.fda.gov/NewsEvents/Newsroom/PressAnnouncements/ucm622252.htm

U.S. Government Accountability Office. (2016, August). Generic drugs under Medicare: Part D generic drug prices declined overall, but some had extraordinary price increases. Retrieved from https://www.gao.gov/assets/680/679022. pdf

How to cite this article: Hemphill T. A. Generic drug competition: The pharmaceutical industry "gaming" controversy. Bus Soc Rev. 2019;124:467-477. https://doi.org/10.1111/basr.12186 